\title{
SZÉNDIOXID-ELSZÁMOLÁS A HÁLÓZATI GAZDASÁGBAN
}

\section{CARBON ACCOUNTING IN THE NETWORK ECONOMY}

A globális klímaváltozással kapcsolatos aggodalmakkal és a kapcsolódó nemzetközi szakpolitikával párhuzamosan alakult ki a vállalati szintű üvegházhatású gáz, illetve ezen belül a széndioxid-elszámolás. A hálózati gazdaság korában a globális ellátási láncok széndioxid-elszámolása jelentősen túlmutat a környezetvédelmen mind gazdasági, mind társadalmi szempontból kiemelt fontosságú. A tanulmány egyrészt rendszerező jellegű áttekintést ad a vállalati széndioxid-elszámolás kialakulásáról, fejlődési fázisairól és kihívásairól, különös tekintettel a vállalatok fizikai határain túlnyúló, az ellátási láncok és a termékek teljes életciklusának széndioxid-mérlegére vonatkozóan; másrészt megvizsgálja a vállalatokon túlnyúló kibocsátások elszámolását a magyarországi vállalatok gyakorlatában

A széndioxid-elszámolás koncepcionális hátterének kialakulását és fejlődését a cikkben négy egymásra épülő szakaszra (környezeti számvitel fókusz, közvetlen széndioxid-kibocsátás fókusz, közvetlen és közvetett széndioxid-kibocsátás fókusz, klímahatás-fókusz) bontva tekintik át és értékelik a szerzők. Ezek alapján az látszik, hogy a vállalati széndioxid-elszámolásokban egyre nagyobb szerepet kap a közvetett, a vállalatokon átívelő kibocsátások nyomon követése, amelyet támogat a tanulmányban bemutatott, különösen a közvetett kibocsátások elszámolásának térnyerése óta egyre komplexebbé váló módszertani eszköztár is.

A magyarországi vállalatok elszámolási gyakorlatának elemzése alapján elmondható, hogy a legnagyobb vállalatok már komoly figyelmet fordítanak a széndioxid-elszámolásra, a közvetlen (Scope 1) és a vásárolt energiához kapcsolódó (Scope 2) kibocsátásaikat nagyrészt számszerűsítik, míg az ellátási lánc további részeinél megjelenő (Scope 3) kibocsátások elszámolása ugyanakkor még gyerekcipőben jár.

Kulcsszavak: ellátási lánc, fenntartható fejlődés, hálózati gazdaság, karbonelszámolás, Scope 3, széndioxid-elszámolás, Üvegházhatású Gáz Protokoll (ÜHG Protokoll, Greenhouse Gas Protocol)

Concerns about global climate change and related international policies have led to the development of enterprise-level carbon accounting. In the age of the network economy, carbon accounting for global supply chains goes far beyond environmental protection and is of major economic and social importance. On one hand, the study provides a systematic overview of the evolution, stages and challenges of corporate carbon accounting, with particular reference to the carbon balance of supply chains and the entire life cycle of products; on the other hand, it examines the current practices of Hungarian companies in the field.

The article examines and assesses the evolution and development of the conceptual background of carbon accounting in four stages (environmental accounting focus, direct carbon dioxide focus, direct and indirect greenhouse gas emission focus, climate impact focus). Based on these, it appears that the monitoring of indirect emissions is playing an increasingly important role in corporate carbon accounting, supported by the methodological toolkit presented in the study, especially as the accounting of indirect emissions has become more widespread.

Based on an analysis of Hungarian companies' accounting practices, the largest companies are already paying close attention to carbon accounting, quantifying their direct (Scope 1) and purchased energy (Scope 2) emissions, while the accounting of their emissions related to the other parts of the supply chain (Scope 3), however, are still in their infancy.

Keywords: Supply Chain, Sustainable Development, Network Economy, Carbon Accounting, Scope 3, Carbon Clearing, Greenhouse Gas Protocol (GHG Protocol)

Finanszírozás/Funding:

A szerzők köszönetet mondanak a Nemzeti Kutatási, Fejlesztési és Innovációs Hivatal OTKA K-116472 pályázatán keresztül kapott támogatásért.

\section{Szerzők/Authors:}

Dr. Csutora Mária, egyetemi tanár, Budapesti Corvinus Egyetem (maria.csutora@uni-corvinus.hu)

Dr. Harangozó Gábor, egyetemi docens, Budapesti Corvinus Egyetem (gabor.harangozo@uni-corvinus.hu)

A cikk beérkezett: 2018. 02. 03-án, javítva: 2019. 04. 10-én, elfogadva: 2019. 04. 23-án.

This article was received: 03.02.2019, corrected: 10.04.2019, accepted: 23.04.2019. 
A globális klímaváltozáshoz kapcsolódó aggodalmakkal és a kapcsolódó nemzetközi fejleményekkel párhuzamosan alakult ki és kezdett elterjedni a vállalati szintű üvegházhatású gáz (ÜHG), illetve ezen belül a széndioxid-elszámolás is az elmúlt évtizedekben. Manapság, a hálózati gazdaság korában a globális ellátási láncok széndioxid-elszámolása jelentősen túlmutat a környezetvédelmen mind gazdasági, mind társadalmi szempontból kiemelt fontosságú.

Az elmúlt évtizedekben az éghajlatváltozás a világ hat legnagyobb fenntarthatósági problémájának egyikévé vált, az erdőirtással, a biológiai sokféleség csökkenésével, a túlnépesedéssel, a szegénységgel és az ivóvízhiánnyal egyetemben (IPCC, 2007, Stern, 2007), amely a másik öttel is jelentősen összefonódik.

Mindezen folyamatok ismeretében különösen fontos, hogy olyan koncepcionális és módszertani kerettel rendelkezzünk vállalati szinten is, amely lehetővé teszi a globális munkamegosztásban az ÜHG, ezen belül különösen a széndioxid-kibocsátás pontos elszámolását és a felelősségek meghatározását. A tanulmány célja kettős:

- egyrészt áttekintést kíván nyújtani a vállalati széndioxid-elszámolás kialakulásáról, fejlődési fázisairól és kihívásairól, különös tekintettel a vállalatok fizikai határain túlnyúló, az ellátási láncok és a termékek teljes életciklusának széndioxid-mérlegére vonatkozóan,

- másrészt a magyarországi vállalatok gyakorlatán keresztül azt vizsgálja, mennyire jelennek meg a vállalatokon átívelő kibocsátások a vállalati elszámolásokban.

A 2. fejezetben bemutatjuk a Scope 3 elszámolásokkal kapcsolatban kialakult nemzetközi diskurzust. A 3. fejezetben a széndioxid-elszámolás koncepcionális hátterét vizsgáljuk meg. Ezen belül bemutatjuk a terület fejlődésének hátterében álló folyamatokat, négy egymásra épülő szakaszra bontva áttekintjük és értékeljük a vállalati széndioxid-elszámolás fejlődését, illetve bemutatjuk a vállalati és vállalatokon átívelő széndioxid-elszámolás szempontjából kiemelten fontos Üvegházhatású Gáz Protokollt. A 4. fejezetben áttekintjük a vállalati, illetve az ellátási láncokra vonatkozó széndioxid-elszámolás legfőbb gyakorlati kérdéseit. Ezek közé tartozik a számszerüsítés legfőbb irányainak bemutatása (folyamatalapú, input-output modellezésen alapuló és hibrid), a rendszerhatárok kijelölésének problematikája és a jelentéstétel legfontosabb kérdéseinek lehatárolása. Az 5. fejezetben a magyarországi nagyvállalatok széndioxid-elszámolási gyakorlatát vizsgáljuk meg, különös tekintettel a vállalaton túlnyúló hatások számszerüsítésére, illetve az ellátási lánc mentén történő kibocsátáscsökkentésre vonatkozó stratégiáikra vonatkozóan. Végezetül a 6. fejezetben összefoglaljuk a cikk legfontosabb megállapításait és kiemeljük a legfontosabb nyitott kérdéseket.

\section{A közvetett széndioxid-elszámolásokra vonatkozó nemzetközi diskurzus}

A nemzetközi kutatási diskurzus különösen a közvetett, vállalatokon átívelő hatások számszerüsítésének terjedésére, a szabványosítás kérdéskörére, a számszerüsítendő hatásokra, a széndioxid-emisszió csökkentési stratégia és a mérésekösszekötésérekoncentrál. A kutatások intenzitásának növekedését katalizálja, hogy a vállalatokat egyre erősebben teszik felelössé beszállítóik vagy termékeik környezeti kudarcaiért, s ennek nyomán terjed a közvetlen kibocsátások elszámolásának gyakorlata a világon. 2017-ben a Carbon Disclosure Project (CDP) keretében jelentő vállalatok közül 2800 jelentette a nem kötelező, közvetett emissziókat is, ezek 26,7\%-a pedig minden általuk lényegesnek minősített kategóriában kiszámolta az emissziót. Ezek közül 368 konkrét célértékeket is megfogalmazott a közvetett kibocsátások csökkentésére vonatkozóan (Farsan et al., 2018).

Az ellátási láncokra kiterjedő széndioxid-számvitel használata különösen azon vállalatok és területek esetében javasolt, ahol:

- a vállalatnak nagyon jelentős upstream és downstream hatásai vannak,

- ezeket a vállalat tudja legjobban befolyásolni.

Gelei és Nagy (2017) arra hívja fel a figyelmet, hogy a nemzetköziesedés és a globalizáció nagy hatást gyakorol az ellátási láncok, hálózatok összetettségének növekedésére. A nemzetközi vállalatok által megvalósított intenzív outsourcing (kiszervezés) és offshoring (kihelyezés) révén igen komplex üzleti hálózatok jöttek létre.

Az ellátási láncot figyelmen kívül hagyó széndioxidelszámolás téves következtetésekre vezethet bennünket. Az Apple és a Samsung termékköre és emissziós profilja például igen hasonló. Az Apple azonban termelési tevékenysége döntő részét kiszervezi, ezért közvetlen emissziója lényegesen alacsonyabb, mint a Samsungé (Farsan et al., 2018). Téves lenne azonban ebből azt a következtetést levonni, hogy az Apple környezettudatosabb vagy kisebb környezeti hatásokkal müködő vállalat, hiszen az egész ellátási láncot figyelembe véve ez nem feltétlenül van így. A Samsung ráadásul az Apple egyik fó beszállítója, az Iphone-ok gyártásához Samsung alkatrészeket is felhasználnak, ezért az Iphone-ok gyártásához kapcsolódó széndioxid-kibocsátás egy része is a Samsungnál jelentkezik. Az sem állítható, hogy az Apple-nek nincsen lehetősége beszállítói fenntarthatósági teljesítményének befolyásolására, hiszen a jelentős publicitást kapott esetekben ezt már megtette, a rossz munkakörülmények miatt 18 beszállítójával szakította meg a kapcsolatot a „Supplier Code of Responsibility"-re való hivatkozással (Lee \& Vachon, 2016).

Patchell (2018) felhívja ugyanakkor a figyelmet arra, hogy az ellátási láncok rendkívül komplexek, a teljes körü adatgyüjtés forrásigénye túlságosan nagy, és ezzel lényeges erőforrásokat vonhat el olyan területekről, ahol a vállalat komolyabb eredményeket tudna elérni.

Lényeges, hogy a vállalati mérések azokra a kérdéskörökre koncentráljanak, amelyeken a vállalat lényeges változtatást tud elérni, ne csupán azokra, amelyek könnyen számszerűsíthetők. Fontos továbbá, hogy a számszerűsítés megalapozza a stratégiaalkotást, a vállalati jelentések 
ne öncélúak legyenek, hanem támogassák a menedzsmentet. A kutatások egy része ezért a közvetett hatások mérésének összhangját vizsgálja a lényegességi szempontokkal és a vállalati stratégiával.

Az általunk végzett kutatás a legnagyobb magyar vállalatok esetében vizsgálja a fenti trendek érvényesülését, azaz 1) a közvetett kibocsátások jelentésének elterjedtségét, 2) azt, hogy a vállalatok inkább a nagy hatásokra koncentrálnak vagy azokra, amelyeket könnyü számszerüsíteni, illetve 3) a jelentéshez kapcsolódik-e a csökkentésre irányuló stratégia. Vajon a nemzetközi trendek élvonalába tartoznak-e nagyvállalataink, legalább követik azt, vagy nem emelték be környezetimenedzsment-gyakorlatukba ezeket a trendeket? Minthogy a közvetett kibocsátások mérésére vonatkozóan a magyar nyelvü szakirodalomban nem jelent meg rendszerező igényü munka, lényegesnek tartottuk, hogy hiánypótló céllal az empirikus eredmények ismertetése előtt a széndioxid-elszámolás történetére és gyakorlati módszertani kérdéseire is részletesen kitérjünk.

\section{A vállalati széndioxid-elszámolás háttere}

Az éghajlatváltozás és a nemzetközi klímapolitika fejleményeivel párhuzamosan megjelent a vállalati szektor széndioxid-kibocsátásának (más kifejezéssel karbonkibocsátásának) mérésére és kezelésére vonatkozó igény is. A vállalati széndioxid-elszámolásra vonatkozóan nincsen egyetlen, általánosan elfogadott definíció (Stechemesser \& Günther, 2012), tartalmilag a vállalati szektor széndioxid-kibocsátásának mérését, kiszámítását, ellenőrzését és kommunikálását foglalja magában (Burritt \& TingeyHolyoak, 2012). Az elszámolás történhet egyrészt természetes mértékegységben (például tonna, $\mathrm{kg}$, illetve ha az elszámolást kiterjesztjük a többi ÜHG-ra is, akkor $\mathrm{CO}_{2} \mathrm{e}-$ azaz $\mathrm{CO}_{2}$-egyenérték), de akár pénzegységben is, számba véve a kapcsolódó költségeket vagy hasznokat.

Schaltegger és Csutora (2012) a széndioxid-elszámolás tudományos, politikai, gazdasági és vállalati szintjeit különböztetik meg. Megközelítésükben a tudományos széndioxid-elszámolás a kibocsátás fö tendenciáit követi nyomon a fenntartható fejlődés perspektívájából vizsgálódva. A politikai és gazdasági karbonelszámolás lehetővé teszi az ökológiai információk gazdasági szempontú értelmezését és így az üzleti szektorra irányuló szakpolitikai intézkedések megalapozását. Végül, de nem utolsósorban, a vállalati szintű széndioxid-elszámolás a vállalatok éghajlatváltozásra gyakorolt hatásának kimutatására és az ezt kézbentartó intézkedéseik eredményességének vizsgálatára használható.

\section{A vállalati széndioxid-elszámolás fejlődésében szerepet játszó folyamatok}

A klímaváltozás fő okai - és hatásai - közvetlenül kapcsolódnak a gazdasági tevékenységekhez, például a fosszilis tüzelöanyagok felhasználásához, a villamos energia termeléséhez, a szállításhoz, a fütéshez és az ipari folyamatokhoz, mivel ezek a tevékenységek a széndioxidkibocsátás fő forrásai (IEA, 2011). Az éghajlatváltozás elleni küzdelem tehát a fenntartható fejlődés egyik központi témája (Banuri, 2009). A terület korai fejlődésének jelentős mérföldköve volt az 1997-es év, ekkor írták alá a nemzetközi klímapolitika szempontjából azóta is meghatározó Kiotói Megállapodást, amely összesen hat üvegházhatást okozó gáz (amelyek közül a szén-dioxid klímaváltozáshoz való hozzájárulása a legjelentősebb) kibocsátásának globális szintű csökkentését tűzte ki célul. Szintén ebben az évben alakult meg az Environmental Management Accounting Network (EMAN), amely azóta is jelentős szerepet játszik vállalati szintü környezeti számvitel fejlődésében és terjedésében.

A széndioxid-kibocsátás csökkentésének szükségessége ellenére az ÜHG-kibocsátás világszerte nő (Boden et al., 2017), ami a környezet állapotának degradálódásán keresztül pénzben kifejezhető károkkal is jár (vö. Marjainé Szerényi \& Kocsis, 2018). Ez nagyrészt a nagy feltörekvő gazdaságok - például Kína és India - kibocsátásainak megdöbbentő mértékü növekedésének köszönhető, míg más nagy gazdaságok, különösen az Egyesült Államok, nem voltak hajlandók vagy képesek csökkenteni a már meglehetősen magas kibocsátási szintjüket. A Párizsi Csúcs fejleményei azt mutatják, hogy a legtöbb ország, úgy tünik, nyitott a széndioxid-kibocsátásuk csökkentésére, hiszen 2016-ra 175 ország írta alá a megállapodást (UNFCCC, 2016), még ha vannak is kérdőjelek a megvalósítással kapcsolatban (elég csak az Egyesült Államok közelmúltban bejelentett kilépési szándékára gondolni). A klímatárgyalások játékelméleti oldalról is vizsgálhatók, egyrészt a döntési helyzetet mátrixjáték-alapú elemzésével (Szendrey \& Karcagi-Kováts, 2016), másrészt a klímaegyezmények historikus tapasztalatai alapján történő elörejelzésekkel (Szendrey \& Karcagi-Kováts, 2018).

Az elmúlt két évtizedben számos európai ország sikeresen szétválasztotta az ÜHG-kibocsátását a GDP-növekedéséről (EGT, 2010), az erre való törekvés az Európai Unió tagállamainak területi politikai gyakorlatában is megjelent, például az integrált városfejlesztési koncepciókban (Pintér, 2015). Első pillantásra ez azt sugallja, hogy az éghajlat-politika Európában sikeres, példát mutatva a világ más régiói számára. A széndioxid-kibocsátás visszaszorítása európai szinten a gazdasági növekedés fenntartása mellett azonban csak részben tekinthető a hatékonyság javulás eredményének. A kibocsátás egy részét „exportáltuk” az ipari termelés Ázsiába történő elmozdulásával. Weber és munkatársai (2008) kimutatták, hogy 2005-ben a kínai kibocsátás mintegy egyharmada az exporttermeléshez kapcsolódott és ez a részesedés azóta is nő. Magyarország esetében például ez a fajta széndioxid-import Kínából hatszorosára nőtt 2000 és 2008 között (Csutora \& Mózner, 2008; Vetőné Mózner, 2012). Továbbá az iparágak között jelentős különbségek vannak: míg az európai feldolgozóipar az elmúlt húsz évben csökkentette az éghajlatváltozásra gyakorolt hatását, a közlekedési ágazat ugyanakkor az emissziók gyors növekedését okozta ugyanebben az időszakban (IEA, 2011). Hasonló fejlemények figyelhetők meg az Egyesült Államokban is, kiegészítve azzal, hogy a közvetlen széndioxid-kibocsátás még az ipari termelés Ázsiába történő kitelepítése ellenére is nött. 


\section{A vállalati széndioxid-elszámolás fejlődésének szakaszai}

Az elmúlt húsz évben a széndioxid-elszámolás mind a vállalatok, mind a tudományos szféra szempontjából fontos terület volt, ugyanakkor a fókusz és a fö kérdések jelentősen átalakultak ebben az időszakban. A vállalati széndioxid-elszámolás fejlődését négy fejlödési fázisba soroltuk be, ezeket tekintjük át röviden a következőkben.

\section{1. szakasz: A széndioxid-elszámolás mint a vállalati környezeti számvitel egyik területe}

A környezeti számvitel eredetileg nem az egyes környezeti tényezők (mint például légszennyezés, vízszenynyezés, hulladék stb.), hanem funkcionális területek mentén fejlödött ki. Ilyen területek például a környezetterhelés fizikai, természetes mértékegységekben történő elszámolása, az anyag- és energiaáram-elemzések, a környezeti költségszámítás, környezeti kontrolling és a környezeti jelentéstétel (lásd például Schaltegger \& Burritt, 2000). A széndioxid-kibocsátás, illetve ennek pénzügyi vonatkozásai mindegyik kategóriában helyet kaptak, bár inkább csak példaként, mintsem kiemelt területként.

Míg a fizikai elszámolás például a szén-dioxid és egyéb üvegházhatású gázok mennyiségét összesíti (Bennett \& James, 1998), a környezeti költségszámítás a kapcsolódó pénzügyi költségekre összpontosít, mint például a széndioxid-adók és a forgalomképes kibocsátási engedélyek költségei. A környezeti kontrolling pedig magában foglalta például az energiamegtakarítások révén elért pénzügyi előnyök kimutatását (Jasch, 2003). Ez a megközelítés messze túlmutatott a korábbi gyakorlaton, amikor is a környezeti költségek számbavétele kimerült a tisztítási költségek és a bírságok összesítésén.

\section{2. szakasz: A széndioxid-elszámolás kiemelt területként való megjelenése}

A környezeti számvitel fejlődése során egyre nagyobb figyelmet kapott a klímavédelem és így a vállalati széndioxid-kibocsátás nyomon követése. A 2000-es évek elejétôl az üvegházhatást okozó gázok kibocsátását már nem egyfajta légszennyező kibocsátásnak tekintették, hanem inkább a környezetvédelmi számvitel önálló, kiemelt területének. Az európai állampolgári felmérések (Eurobarometer, 2007; 2011) is alátámasztják, hogy az éghajlatváltozással kapcsolatos társadalmi érdeklődés olyan mértékben megnőtt, hogy ezt a területet tartotta az európai lakosság a fenntarthatósággal kapcsolatos legfőbb problémának, még akkor is, ha a ráirányuló figyelem a pénzügyi válságot követően némiképp háttérbe is szorult. A politikai és szabályozási szinten történő előrelépések, mint például a Kiotói Jegyzőkönyv, az EU kibocsátáskereskedelmi rendszere vagy az Ausztráliában bevezetett széndioxid-adók (Pellegrino \& Lodhia, 2012) az önkéntes vállalati kezdeményezéseken túl szintén fontos szerepet játszottak a vállalati szintủ széndioxid-elszámolás fejlődésében (függetlenül attól, hogy a vállalatvezetők személyesen hittek-e a klímaváltozásban vagy környezettudatosak voltak-e).

$\mathrm{Az}$ ÜHG-kibocsátás elszámolása, menedzsmentje, illetve az ezzel kapcsolatos jelentéstétel mára már fel- sővezetői szintủ terület a vezető vállalatoknál. A terület fejlődésével párhuzamosan egyre nagyobb igény van az elszámolás szabványosítására is (lásd később).

\section{3. szakasz: Ellátási láncokon átívelő széndioxid-elszámolás}

A fejlett országok esetében az üvegházhatású gázok nagy és egyre növekvő hányada az importált termékeken keresztül, , karbonhátizsák” formájában kerül a rendszerbe (von Weizsäcker et al., 1997; von Weizsäcker, 2009). Ezen túlmenően a termékek $\mathrm{CO}_{2}$-intenzitása is gyakran nőtt, részben a több szállítási szakasz és a hosszabb szállítási távolság miatt.

Ugyan a vállalati szintủ széndioxid-elszámolás sokat fejlődött, a globális ellátási láncok és a hálózati gazdaság korában egyre félrevezetőbb, ha a vállalati szintű elszámolás csak a közvetlen kibocsátásokkal foglalkozik. A vállalatok javuló környezeti teljesítménye és az ennek ellenére növekvő karbon kibocsátás között feszülő ellentmondás rávilágít arra, hogy a karbonkibocsátások vizsgálatakor át kell lépni a vállalatok fizikai és virtuális határait. A széndioxid-elszámolásban egyre nagyobb szükség van a teljes ellátási láncok és a termékéletciklusok nyomon követésére, beleértve a feldolgozóipar által importált félkész termékek által okozott kibocsátásokat is. Az ellátási láncok növekvő mérete azonban komoly kihívást jelent az ilyen típusú széndioxid-elszámolásra (Görbe \& Gelei, 2014), ezzel párhuzamosan ugyanakkor megjelentek az ellátási lánc különböző területeit (például beszerzés, logisztika) lefedő jó gyakorlatok is (Vörösmarty \& Dobos, 2019; Kovács et al., 2018; Pónusz \& Kozma, 2017).

Jelenleg a vállalati és vállalatokon átívelö széndioxidelszámolás legelterjedtebb kerete és nemzetközi szabványa az Üvegházhatású Gáz Protokoll (Greenhouse Gas Protocol, a továbbiakban ÜHG Protokoll), amelyet a Fenntartható Fejlödés Üzleti Világtanácsa (World Business Council for Sustainable Development) és a World Resource Institute dolgozott ki (WBCSD/WRI, 2004; 2011).

\section{4. szakasz: A széndioxid-elszámolástól a klímahatás-elszámolásig}

A széndioxid-elszámolás szélesebb értelemben utalhat az üvegházhatású gázok nagyobb csoportjára, amelyek a Kiotói Jegyzőkönyv hatálya alá tartoznak: dinitrogén-oxid $\left(\mathrm{N}_{2} \mathrm{O}\right)$, metán $\left(\mathrm{CH}_{4}\right)$, fluorozott szénhidrogének (HFC), perfluor-szénhidrogének (PFC) és kén-hexafluorid $\left(\mathrm{SF}_{6}\right)(\mathrm{CCAR} 2008$ és OPEN: EU, 2010). Ha az elszámolás hatóköre kiterjed az üvegházhatást okozó gázok szélesebb körére, akkor a széndioxid-elszámolás fogalma némileg félrevezetô, mivel más, nem széndioxid-alapú üvegházhatást okozó gázok is szerepelnek (Downie \& Stubbs, 2013; Meisterling et al., 2009) benne. Ebben az esetben az ÜHG-elszámolás vagy a klímahatás-elszámolás (climate accounting) kifejezések megfelelőbbek lehetnek.

Ezen túlmenően a klímahatás-elszámolás fogalma még tágabb, mivel nemcsak a kibocsátott mennyiségekre, illetve kapcsolódó költségekre és hasznokra, hanem az éghajlatváltozás mérséklésére tett erőfeszítésekre és az alkalmazkodás költségeire is kiterjed (Stechemesser et al., 2015). Ide 
tartozhat például a klímaváltozás miatti megnövekedett hütési költség vagy a mezőgazdasági kilátások romlása miatti terményár-növekedés (mint vállalati input). A jövőben az ide tartozó költségek növekedése várható. Összességében tehát a klímahatás-elszámolás egyrészt magába foglalja a vállalat klímaváltozáshoz hozzájáruló kibocsátásait fizikai mértékegységben - a szén-dioxidtól különböző ÜHG$\mathrm{k}$ esetében $\mathrm{CO}_{2}$-egyenértékben - vagy pénzben; másfelől kiterjed a klímaváltozás által a vállalatnál jelentkező hatásokra, elsősorban pénzben kifejezve (például magasabb biztosítási díjak, változó energiaköltségek).

A széndioxid-elszámolás négy szakaszát az 1. táblázat összegzi. láncon átívelő közvetett kibocsátásaik elszámolására. Az ÜHG Protokoll a kibocsátásoka ${ }^{1}$ három kategóriába sorolja (ezekre a továbbiakban az eredeti Scope kifejezést használjuk, az 1. körös, 2. körös, 3. körös magyar nyelvü kifejezés nem igazán honosodott meg a gyakorlatban):

- Scope 1: közvetlen energiafelhasználás következtében jelentkezö kibocsátás. Ide tartozik a saját tulajdonú kazánok vagy a saját gépjármüvek által kibocsátott $\mathrm{CO}_{2}$, valamint a technológiai jellegü széndioxid-kibocsátás.

- Scope 2: felhasznált köztes energia elöállitása által okozott kibocsátás. Sok esetben a felhasznált energia nem az adott vállalatnál, hanem az azt előállító be-

1. táblázat A széndioxid-elszámolás fejlődési fázisai. Forrás: saját szerkesztés

\begin{tabular}{|c|c|c|c|c|}
\hline & Szakasz & Jellemzők & Kiváltó okok & Fókusz \\
\hline 1. & Környezeti számvitel & $\begin{array}{l}\text { A széndioxid-kibocsátás } \\
\text { egy példa a környezeti } \\
\text { számvitelen belül }\end{array}$ & $\begin{array}{l}\text { Növekvő érdeklődés } \\
\text { a vállalati környezeti } \\
\text { költségek iránt }\end{array}$ & $\begin{array}{l}\text { Ökohatékonyság, } \\
\text { költségtakarékosság, } \\
\text { erőforrás-hatékonyság }\end{array}$ \\
\hline 2. & $\begin{array}{l}\text { Széndioxid-elszámolás } \\
\text { (közvetlen kibocsátások) }\end{array}$ & $\begin{array}{l}\text { A széndioxid- kibocsátás } \\
\text { kiemelt terület }\end{array}$ & $\begin{array}{l}\text { Növekvő társadalmi és } \\
\text { szabályozói } \\
\text { klímatudatosság }\end{array}$ & $\begin{array}{l}\text { A szervezeti szintü } \\
\text { széndioxid-kibocsátás } \\
\text { számvitele és kommunikálása }\end{array}$ \\
\hline 3. & $\begin{array}{l}\text { Széndioxid-elszámolás } \\
\text { (közvetlen és közvetett } \\
\text { kibocsátások) }\end{array}$ & $\begin{array}{l}\text { Az ellátási lánc és } \\
\text { a termékéletciklus } \\
\text { az elszámolási egység }\end{array}$ & $\begin{array}{l}\text { Növekvő figyelem } \\
\text { a globális ellátási láncok } \\
\text { környezeti hatásaira }\end{array}$ & $\begin{array}{l}\text { Az ellátási láncok és } \\
\text { a termékéletciklusok } \\
\text { széndioxid-kibocsátásának } \\
\text { rendszerszintű számszerűsítése }\end{array}$ \\
\hline 4. & Klímahatás-elszámolás & $\begin{array}{l}\text { A széndioxid-kibocsátás } \\
\text { mellett további területek } \\
\text { vizsgálata }\end{array}$ & $\begin{array}{l}\text { A kibocsátáshoz } \\
\text { kapcsolódó költségek } \\
\text { mellett az alkalmazkodási } \\
\text { költségek is } \\
\text { egyre jelentősebbek }\end{array}$ & $\begin{array}{l}\text { Az ellátási láncok és } \\
\text { a termékéletciklusok összes } \\
\text { klíma vonatkozású hatásának és } \\
\text { költségének számbavétele }\end{array}$ \\
\hline
\end{tabular}

Az egyes szakaszok időben némileg átfednek, mivel a tudományos közösség már jóval korábban elkezdett az egyes területekkel foglalkozni, mint ahogy azok a gyakorlatban széleskörüen elterjedtek volna. Mindezt figyelembe véve az 1. szakasz az 1990-es évek végét, illetve a 2000-es évek elejét fedi le, míg a 2. szakasz a 2000-es évek elején és közepén volt a domináns megközelítés. Bár a tudományos viták szempontjából már a 2000-es évek közepe óta a közvetett széndioxid-kibocsátás (3. szakasz) áll a középpontban, néhány módszertani kérdés még most is nyitott, illetve a közvetett kibocsátások vállalati nyomon követése még manapság is gyerekcipőben jár. Végül, de nem utolsósorban, az éghajlatváltozással kapcsolatos kérdések vállalati vonatkozásaival (4. szakasz) csak a 2010-es években kezdtek foglalkozni és valószínűleg még sokáig napirenden lesznek.

\section{Az Üvegházhatású Gáz Protokoll szerepe a vállalatokon átívelö széndioxid-kibocsátás elszámolásában}

A korábban említett ÜHG Protokoll nagy segítséget nyújt a vállalatok számára a közvetlen, illetve az ellátási szállítónál jár $\mathrm{CO}_{2}$-kibocsátással. Ezek közül a legfontosabb az elektromos áram, de ide tartozik a távfütőmüvek által szolgáltatott hő, vagy a más szervezettől vásárolt gőz is. A köztes energiához kapcsolódó kibocsátásoknál figyelembe kell venni az energia átalakítása és szállítása során fellépő veszteségeket is. Fontos kiemelni, hogy a szervezetek Scope 2 kibocsátásának nagyságára jelentős hatást gyakorol az adott ország villamosenergia-mixe is, vagyis, hogy milyen elsődleges energiából állítják elő a villamos energiát.

- Scope 3: egyéb, az ellátási láncon átívelö közvetett kibocsátások. Az ide tartozó kibocsátások összefüggésben vannak a vállalat tevékenységével, de olyan forrásokból származik, amelyeket a vállalat sem pénzügyi, sem pedig működési kontroll alatt nem tart. Ide tartoznak például az alkalmazottak mobilitásához, a bérelt üzleti flottához, nyersanyag kitermeléshez kapcsolódó vagy akár a termék használata, a hulladékfeldolgozás vagy az építési tevékenység során jelentkező kibocsátások (lásd bővebben a 2. táblázatban).

\footnotetext{
1 Itt is megjelenik a dilemma, hogy kizárólag a szén-dioxidra vagy az ÜHG-k szélesebb körére fókuszáljunk. Az ÜHG Protokoll kerete mindkettőre lehetőséget biztosít, az egyszerűség kedvéért (illetve figyelembe véve, hogy a legtöbb vállalat esetében csak a széndioxid-kibocsátás releváns), ebben a részben a széndioxid-elszámolásra összpontosítunk. Többféle ÜHG számbavétele esetén bevett gyakorlat a széndioxid-egyenértékre való átszámítás.
} 
2. táblázat Az ellátási lánc mentén jelentkező, a vállalat határain túli, Scope 3 üvegházgáz-kibocsátások forrásai. Forrás: WBCSD/WRI, 2011), illetve részarányuk Toyota Global vállalatcsoportnál, 2018-ban

(adatok forrása: Toyota, 2018, p. 94.)

\begin{tabular}{|l|c|l|c|}
\hline \multicolumn{1}{|c|}{ Upstream tevékenységekhez kapcsolódó } & $\begin{array}{c}\text { Részarány } \\
\text { a Toyotánál } \\
\text { (\%) }\end{array}$ & \multicolumn{1}{|c|}{$\begin{array}{c}\text { Downstream tevékenységekhez } \\
\text { kapcsolódó }\end{array}$} & $\begin{array}{c}\text { Részarány } \\
\text { a Toyotánál } \\
\text { (\%) }\end{array}$ \\
\hline 1. Vásárolt áruk és szolgáltatások & $14,9 \%$ & 9. Downstream szállítás és elosztás & $<0,1 \%$ \\
\hline 2. Tökejavak & $1 \%$ & 10. Eladott áruk feldolgozása & $0,3 \%$ \\
\hline $\begin{array}{l}\text { 3. Üzemanyag- és energiafelhasználással járó } \\
\text { tevékenységek (ami nem Scope 1 vagy Scope 2) }\end{array}$ & $0,2 \%$ & 11. Eladott áruk használata & $82,2 \%$ \\
\hline 4. Upstream szállítás és elosztás & $0,2 \%$ & $\begin{array}{l}\text { 12. Eladott áruk kezelése életciklusuk } \\
\text { végén }\end{array}$ & $0,9 \%$ \\
\hline 5. A müködés során termelt hulladékok kezelése & $<0,1 \%$ & 13. Downstream bérelt eszközök & - \\
\hline 6. Üzleti utak & $<0,1 \%$ & 14 . Franchise & - \\
\hline 7. Dolgozók közlekedése & $0,2 \%$ & 15 . Beruházások & $<0,1 \%$ \\
\hline 8. Bérelt eszközök & - & & \\
\hline
\end{tabular}

Az egyes területekhez tartozó kibocsátások számszerüsítése segíthet a prioritások meghatározásában is. A Toyota esetében például a vásárolt árukhoz (14,9\%), de különösen az eladott termékekhez, például gépjármüvekhez $(82,2 \%)$ tartozik a legnagyobb kibocsátás, ezek mellett eltörpülnek például az üzleti utakhoz, vagy a dolgozók munkába járásához kapcsolható kibocsátások. Ez alapján, ha a Toyota érdemben szeretné csökkenteni az ellátási lánca mentén jelentkező széndioxid-kibocsátást, érdemesebb a beszállítói elvárások finomítására, illetve a termékfejlesztésre koncentrálnia, tekintve, hogy a látványos és jól kommunikálható utazászöldítési programok - még ha a környezeti nevelés szempontjából tekintett fontosságukat nem is vonjuk kétségbe - eredményessége ennél jóval alacsonyabb.

A Scope 3 kibocsátásoknak csak egy része becsülhető a vállalatnál rendelkezésre álló adatok alapján, míg a hatások egy része csak összetett, hibrid elszámolási módszerek segítségével közelíthetők (lásd később).

A széndioxid-kibocsátás különböző szintjei közötti kapcsolatot szemlélteti az 1. ábra és a 3. táblázat a villamos energia ellátási láncán keresztül.

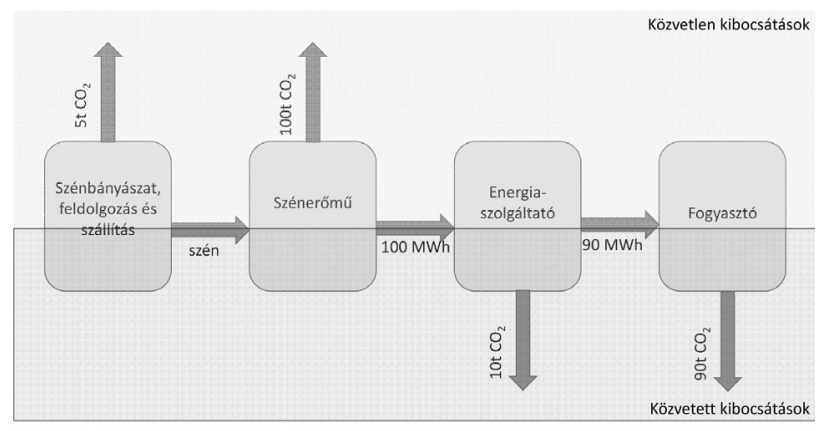

1. ábra A villamos energia ellátási láncának közvetlen és közvetett kibocsátásai (a számok illusztratívak).

Forrás: Corporate Value Chain Accounting Reporting Standard, GHG Protocol, WBCSD/WRI, 2011, p. 42. alapján
3. táblázat A villamos energia ellátási láncának Scope 1, Scope 2 és Scope 3 széndioxid-kibocsátásai az ellátási lánc különböző szereplőinek perspektívájából

Forrás: Corporate Value Chain Accounting Reporting Standard, GHG Protocol, WBCSD/WRI, 2011, p. 43. alapján

\begin{tabular}{|c|c|c|c|}
\hline $\begin{array}{c}\text { Jelentést } \\
\text { tevő } \\
\text { vállalat }\end{array}$ & $\begin{array}{c}\text { Scope } \\
1\end{array}$ & Scope 2 & Scope3 \\
\hline $\begin{array}{l}\text { Bánya- } \\
\text { vállalat }\end{array}$ & $5 \mathrm{t}$ & - & $\begin{array}{l}100 \text { t } \\
\text { (eladott termékek } \\
\text { felhasználásához } \\
\text { kötődő) }\end{array}$ \\
\hline Szénerőmü & $100 \mathrm{t}$ & & $\begin{array}{l}5 \text { t (üzemanyag- és } \\
\text { energiafelhaszná- } \\
\text { lással járó } \\
\text { tevékenységek) }\end{array}$ \\
\hline $\begin{array}{l}\text { Energia- } \\
\text { szolgáltató } \\
\text { vállalat }\end{array}$ & - & $\begin{array}{l}10 \mathrm{t} \\
\text { (hálózati } \\
\text { veszteség) }\end{array}$ & $\begin{array}{l}0,5 \text { t } \\
\text { (szénbányászat, } \\
\text { feldolgozás és } \\
\text { szállítás) } \\
94,5 \text { t } \\
\text { (az energia- } \\
\text { termelésből) }\end{array}$ \\
\hline $\begin{array}{l}\text { Fogyasztó } \\
\text { vállalat }\end{array}$ & - & $\begin{array}{l}90 \mathrm{t} \\
\text { (felhasznált } \\
\text { energia } \\
\text { termeléséhez } \\
\text { kapcsolódó } \\
\text { rész) }\end{array}$ & $\begin{array}{l}4,5 \text { t } \\
\text { (szénbányászat, } \\
\text { feldolgozás és } \\
\text { szállítás) } \\
10,5 \text { t } \\
\text { (az energia- } \\
\text { termelésböl) }\end{array}$ \\
\hline
\end{tabular}

Látható, hogy az egyes kibocsátások más Scope-ba tartoznak, aszerint, hogy melyik vállalat szemszögéből nézzük. A Scope 1 elszámolások a szervezetek közvetlen kibocsátását adják meg, így ezek összeadásával elvileg a termelő ágazatok összes kibocsátását megkapnánk, amenynyiben minden szervezet elvégezné a számításokat. (A lakosságnál jelentkező fütési, közlekedési és egyéb közvetlen kibocsátások - főzés, égetés - ugyanekkor ez esetben sem szerepelnének a kimutatásban.) A Scope 1 kibocsátások 
azonban nem adhatók össze a Scope 2 kibocsátásokkal, mivel az kétszeres elszámolást okozna. (Az elektromos energia az előállító erőműnél Scope 1-ként, a felhasználónál viszont Scope 2-nél is nyilván lenne tartva.) A Scope 3 elszámolások esetében pedig akár sokszorozódásról is beszélhetünk, hisz az ellátási lánc bármely szereplöje kimutathatja a más szereplöknél jelentkező kibocsátásokat (a saját tevékenységéhez tartozó Scope 3 kibocsátásként).

A Scope 3 kibocsátásokat sok vállalat annak bemutatására számszerüsíti, hogy a saját közvetlen kibocsátásuk kevéssé jelentős az ellátási lánc más szereplőinek kibocsátásaihoz képest. Ezzel párhuzamosan azonban kirajzolódik, melyek az ellátási lánc szempontjából kritikus, beavatkozást igénylő területek, hot spot-ok.

A Scope 3 kibocsátások ugyan nem a vállalatnál jelentkeznek, azonban sok esetben a vállalatnak nagyobb beavatkozási lehetősége van ezek kontrollálására, mint annak a gazdasági aktornak, ahol azokat ténylegesen kibocsátják. Például egy autógyártó vállalat által eladott személygépjármü széndioxid-kibocsátása a fogyasztónál jelentkezik, azonban a jármü motorjának üzemanyag-hatékonyságára a vállalatnak van csak befolyása, holott az lényeges meghatározója a kibocsátásnak. Egy mosógép energiafelhasználására szintén nemcsak a fogyasztónak, hanem az elöállító vállalatnak is nagy hatása van. A vállalati termelö folyamatok kiszervezésével pedig csökkennek a vállalati Scope 1 kibocsátások anélkül, hogy a teljes termelö folyamat kibocsátása csökkenne, s ezt az upstream Scope 3 kibocsátások számszerüsítésével lehet megfogni.

Az előző példában egy rövid ellátási láncot tekintettünk át, a széndioxid-elszámolás perspektíváját azonban egyetlen termék példáján keresztül is szemléltethetjük. Tegyük fel, hogy egy vállalatnál az anyagmozgatási feladatok elvégéséhez targoncákat használnak. Amennyiben a vállalat csak a közvetlen saját széndioxid-kibocsátását tartja nyilván, akkor a targoncák kibocsátása csak akkor kerül nyilvántartásba, ha azok dízel- vagy benzinüzemüek és a vállalat tulajdonában vannak. Minden más esetben a kibocsátásuk közvetett és a Scope 2 vagy Scope 3 kategóriába kerül.

Minthogy a targoncákat a vállalatnál folyó tevékenységek érdekében használják, érthető és jogos az az elvárás, hogy azok kibocsátását a vállalat akkor is felmérje és kontrollálja, ha azok az ő szempontjából nem számítanak közvetlen kibocsátásnak (Scope 2-be vagy Scope 3-ba tartoznak). A csak közvetlen kibocsátásokra korlátozódó elszámolások figyelmen kívül hagyják a kiszervezett tevékenységeket és az elektromos energia felhasználását. A vállalat csökkentheti széndioxid-kibocsátását a tevékeny- ségek kiszervezésével, amely félrevezető jelzést ad környezeti teljesítményéről (4. táblázat).

Bár a Scope 3 kibocsátások jelentősek, a vállalatok általában alulbecsülik a nagyságukat (Stein \& Khare, 2009 vagy Downie \& Stubbs, 2012). Matthews és szerzőtársai (2008) szerint az egyesült államokbeli vállalatok körében a Scope 1 kibocsátások csak az összes kibocsátás 14\%áért, míg a Scope 1 és Scope 2 kibocsátások együttvéve is csak 26\%-áért felelösek. Ezzel egybecseng Huang és munkatársai (2009) megállapítása, akik szerint a Scope 3 kibocsátások a teljes vállalati mérleg 75\%-át teszik ki.

Blanco et al. (2016) a CDP keretében jelentő amerikai vállalatokat vizsgálva megállapította, hogy míg 2005-ben a jelentett Scope 3 emissziók az összes jelentett emissziónak csak mintegy 15-át adták, addig az az érték 2013-ra 39\%ra nőtt. Azt is megállapították, hogy a Scope 3 emissziók jelentését erősen támogatja az, ha az adott iparág más vállalatai is jelentenek. Megállapították továbbá, hogy a kiterjedt beszállítói hálózat, a sok beszállító léte nem akadálya a Scope 3 hatások becslésének. A Cisco és a Johnson példáján keresztül bemutatják, hogy a vállalat saját beszerzési adatai és a beszállítók mintáján végzett kérdőíves felmérések kombinálásával a Scope 3 hatások becslése eredményes lehet.

Az elmúlt évtizedben jelentős előrelépés történt Európában az üvegházgázok kibocsátásának terén, ez azonban részben csak látszólagos, a kiszervezések és a termelés delokalizációjának - az ázsiai régióba való településnek egyik eredménye (Csutora \& Mózner, 2014). Vagyis a vállalatok Scope 1 és Scope 2 kibocsátásainak csökkentése a Scope 3 kibocsátások növekedésének árán valósult meg.

\section{A széndioxid-elszámolás gyakorlati módszerei}

A terület fejlődésével párhuzamosan a kibocsátások számszerüsítésének módszerei is egyre összetettebbek lettek. Míg a közvetlen kibocsátások nyomon követésére (az előző fejezetben bemutatott osztályozás alapján az 1-2. szakasz) egyszerübb módszerek (mint például anyagáramelemzés vagy energiamérlegek elemzése) is elegendő volt, a széndioxid-elszámolás fejlődésének 3. szakaszától kezdve (amikor a közvetett, vállalatokon átívelő kibocsátások számszerüsítésére is szükség van) egyre összetettebb módszerek jelentek meg. Ezek három csoportba sorolhatók:

- alulról felfelé irányuló (bottom-up) megközelítés: az anyagáram vagy folyamatalapú életciklus-elemzés (Life Cycle Assessment, LCA) egy adott szervezet vagy termék kibocsátását a különböző (rész) folyamatok kibocsátásainak összesítése révén számszerüsíti. Ez a megközelítés pontos értékeket adhat,

4. táblázat Anyagmozgató targoncához kapcsolódó széndioxid-elszámolás különböző esetekben. (Forrás: saját szerkesztés)

\begin{tabular}{|l|c|c|c|c|}
\hline & \multicolumn{2}{|c|}{$\begin{array}{c}\text { Pénzügyi kontroll megközelítésü elszámolás } \\
\text { esetén }\end{array}$} & $\begin{array}{c}\text { Müködési kontroll megközelítésü elszámolás } \\
\text { esetén }\end{array}$ \\
\hline & $\begin{array}{c}\text { A targonca } \\
\text { a vállalat } \\
\text { tulajdonában van }\end{array}$ & $\begin{array}{c}\text { A targoncát } \\
\text { a vállalat bérli }\end{array}$ & $\begin{array}{c}\text { A targoncát } \\
\text { a vállalat üzemelteti }\end{array}$ & $\begin{array}{c}\text { A targoncát } \\
\text { alvállalkozó } \\
\text { üzemelteti }\end{array}$ \\
\hline Diesel targonca & Scope 1 & Scope 3 & Scope 1 & Scope 3 \\
\hline Elektromos targonca & Scope 2 & Scope 3 & Scope 2 & Scope 3 \\
\hline
\end{tabular}


azonban rendkívül összetett és nehéz feladat bizonyos tevékenységek (például autógyártás) esetében, ahol több ezer folyamatot kell áttekinteni (Muller \& Schebek, 2013). A témában egy magyarországi esetet mutatnak be Tóth és szerzőtársai (2018).

- felülröl lefelé irányuló (top-down) megközelítés: a környezeti adatokkal kiegészített pénzügyi folyamatokra építő input-output elemzés segítségével egy vállalat, illetve ellátási lánc széndioxid-kibocsátását becsülhetjük. Az input-output modellt (Leontief, 1936) eredetileg az 1930-as években fejlesztették ki, hogy lehetővé váljon a különböző gazdasági ágazatok közötti kapcsolatok elemzése az egymás közötti tranzakciók figyelembevételével. Ez a modell a természetes mértékegységben kifejezett környezeti adatokkal bővíthető és így alkalmas lehet a széndioxid-elszámolási célokra is (Cagiao, 2011 vagy Townsend \& Barrett, 2013), különösen hosszú ellátási láncok esetén. Az input-output elemzéseknél a nem pontosan nyomon követhető anyagi folyamatokat a jobban dokumentált pénzügyi folyamatok alapján becsüljük. A rendszerhatárok kijelölése azonban problémás lehet (Ozawa-Meida et al., 2013).

- hibrid megközelités: a fenti két megközelítés hiányosságainak kiküszöbölése érdekében azok kombináltan is használhatók (Crawford, 2008). A tapasztalatok azt mutatják, hogy a bottom-up, folyamatalapú megközelítés jobban alkalmazható a downstream kibocsátásoknál, míg a top-down, input-output megközelítés alkalmasabb az upstream kibocsátások mérésére (Suh et al., 2004; Bilec et al., 2006). A széndioxid-elszámolás hibrid megközelítésének számos alkalmazása van. Lenzen (2002) például különböző ausztrál iparágakra alkalmazta, míg Ozawa-Meida és munkatársai (2013) egy brit egyetem Scope 1, Scope 2 és Scope 3 széndioxid-kibocsátását számították ki ilyen módon.

Minden esetben fontos módszertani kérdés, hol húzzuk meg a rendszerhatárokat (Harangozó et al., 2015), azaz meddig terjedjen ki az elemzés az upstream, illetve a downstream irányba (azaz például figyelembe vehetjük a nyersanyag kitermeléshez kötődő széndioxid-kibocsátásokat, de dönthetünk akár úgy is, hogy még a bányagépek előállításának kibocsátásait is figyelembe vesszük).

A 2. ábra az ellátási láncok karbonkibocsátásának elszámolási lehetőségeit foglalja össze.

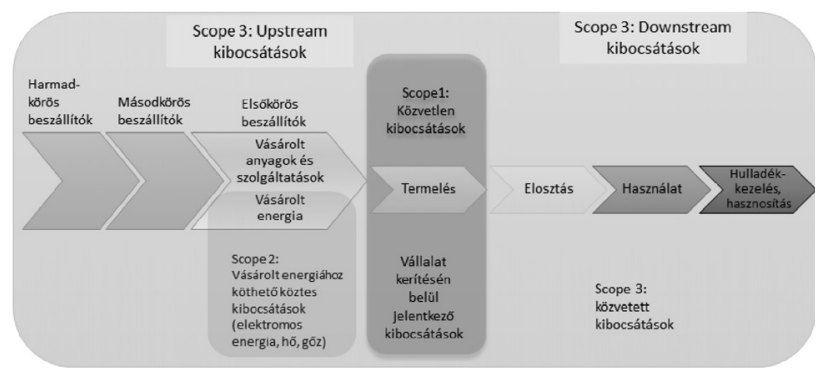

2. ábra Az ellátási lánc mentén történő széndioxid-kibocsátás elszámolása a gazdaságban. (Forrás: saját szerkesztés)
Egy további, már a széndioxid-elszámolás kezdeti szakaszaiban is jelen levő elemzési eszköz a szén- vagy karbonlábnyom-számitás, amely egy tevékenység által közvetlenül és közvetve okozott (Wiedmann et al., 2009; Jungbluth et al., 2012) vagy egy termék teljes életciklusához kötődő (Galli et al., 2012) széndioxid-kibocsátást számszerűsíti. A szénlábnyomot általában szén-dioxidra vetítve, természetes mértékegységben ( $g$, kg vagy t) fejezik ki (Vázquez-Rowe et al., 2013), míg az egyéb üvegházgáz kibocsátásokat $\mathrm{CO}_{2}$-egyenértékben mutatják ki (Panela et al., 2009). A szénlábnyom kifejezést más összefüggésben és más módszertan alapján számítva az ökológiailábnyom-mutató részeként is használják (lásd például Wackernagel et al., 1999; Tóth \& Szigeti, 2016); ebben az esetben a szénlábnyomot globális hektárban mérik. Az ökológiailábnyom-mutató csak a szén-dioxid mennyiségét veszi figyelembe, ezért a más célú szénlábnyom-kalkulációk eredményeinek ökológiailábnyom- számításban való felhasználásakor körültekintően kell eljárni (Szigeti, 2016).

A széndioxid-jelentéstétel szintén a kezdetektől fontos szerepet játszik a széndioxid-elszámolás eredményeinek a különböző háttérrel és érdekekkel rendelkező érintettek számára történő kommunikációban, az elmúlt időszakban ezzel kapcsolatban számos önkéntes keretrendszert dolgoztak ki. A korábban már említett CDP az egyik legfontosabb kezdeményezés, amely önkéntes alapon lehetőséget biztosít a vállalati széndioxid-elszámolás nyilvánosságra hozatalára, elsősorban a befektetők felé történő kommunikáció eszközeként. 2014-ben összesen 5003 vállalat töltötte ki a CDP-kérdőívet, szemben a 2003-as 253mal (CDP, 2016).

A CDP-n túl a nonprofit szektor nagyon aktívan támogatja azokat a további kezdeményezéseket, amelyek a vállalati széndioxid-elszámolást és jelentéstételt ösztönzik. A 2001-ben alapított brit székhelyü Carbon Trust aktívan részt vesz a világ minden táján zajló projektekben. 2016-ig bezárólag a Carbon Trust kezdeményezésében részt vevő vállalatok összesen $60 \mathrm{Mt} \mathrm{CO}_{2}$-kibocsátását előzték meg (Carbon Trust, 2016).

Az ÜHG-kibocsátással kapcsolatos információk nyilvánosságra hozatalára és az érdekelt felek számára történő jelentésére vonatkozó egyéb kezdeményezések például a Global Reporting Initiative (GRI) és az ISO 14031 szabvány iránymutatásai. További támpontot kínál a befektetők számára a vállalatok által jelentett adatok alapján történő besorolások, mint például a Dow Jones Fenntarthatósági Index. A kommunikáció egyik további csatornáját jelentik a termékszintü karboncímkézés (lásd például Carbon Trust, 2008 vagy Scipioni et al., 2012).

Az önkéntes közzététel hasznos eszköz lehet a vállalati környezeti célok és az eredmények közlésére (Tóth et al., 2002-2017; Széchy \& Zilahy, 2018; Zsóka \& Vajkai, 2018; Deutsch \& Pintér, 2018), bár nem nyújt elegendő motivációt minden vállalat számára, különösen, ha a célok nem teljesülnek (Pellegrino \& Lodhia, 2012) vagy esetleg nem is léteznek. Az önkéntes jelentéstétel alternatívája a kötelező jelentéstétel, ami különösen fontos lehet akkor, ha figyelembe vesszük a vállalatok viszonylag alacsony érdeklődését az önkéntes jelentéstétel iránt. Nagy-Britanniában például a 
Környezetvédelmi, Élelmiszer- és Vidékügyi Minisztérium (DEFRA) 2013-es rendelete alapján minden tőzsdén jegyzett társaságnak jelentést kell tennie a Scope 1-es és Scope 2-es széndioxid-kibocsátásáról (DEFRA, 2013); a rendelet eredményeként a hatóságok 2021-re 4 Mt széndioxid-kibocsátáscsökkenést várnak, feltételezve, hogy az adatok pontos ismerete a vállalatokat az energiafelhasználás racionalizálására ösztönzi. A közvetlen ÜHG-kibocsátásokra vonatkozóan egyes tevékenységek Magyarországon is kibocsátási engedély- és jelentéskötelesek, jelenleg a 2012. évi CCXVII. törvény és az annak végrehajtására szolgáló 410/2012. (XII. 28.) kormányrendelet tartalmazza e tevékenységek listáját. Az önkéntes és a kötelezö jelentéstétel által lefedett területeket összegezi az 5. táblázat. nálás, illetve széndioxid-kibocsátás (a $\mathrm{CO}_{2}$-kvótákhoz kötődően) jelentős költségmegtakarítással kecsegtet, akkor valószínü, hogy az érintett vállalatok fejlesztik a széndioxid-elszámolási rendszerüket (legalábbis a Scope 1 és Scope 2 kibocsátásokra vonatkozóan, hiszen az ehhez kapcsolódó költségek vonatkoznak a vállalatra).

- piacvezérelt: ha a piaci szereplők az értéklánc mentén (végső fogyasztók, az ellátási lánc valamennyi B2B - business to business - vásárlója, vagy akár a versenytársak vagy a beszállítók) érdeklődést mutatnak a végtermékekkel vagy az ellátási lánccal kapcsolatos széndioxid-kibocsátásra vonatkozóan, ez elegendő motiváció lehet arra vonatkozóan, hogy a

5. táblázat. A kötelező és önkéntes jelentéstételi rendszerek tartalmának összehasonlítása (Forrás: saját szerkesztés)

\begin{tabular}{|c|c|c|c|}
\hline & $\begin{array}{c}\text { Kibocsátási engedélyköteles és } \\
\text { jelentésköteles tevékenységek } \\
(525 / 2013 / \mathrm{EU} \text { rendelet és } \\
\text { a } 2012 / \mathrm{CCXVII} \text {. törvény } \\
\text { alapján) esetében }\end{array}$ & $\begin{array}{l}\text { A Carbon Disclosure Project-hez } \\
\text { csatlakozó, illetve a Global Reporting } \\
\text { Initiative szabványa alapján jelentést } \\
\text { tevő vállalatok esetében }\end{array}$ & $\begin{array}{l}\text { Egyéb, önkéntesen jelentő } \\
\text { vállalatok esetében }\end{array}$ \\
\hline Scope 1 & $\begin{array}{c}\text { Kötelező, szabályozott, részletes } \\
\text { (többféle üvegházhatású gázra } \\
\text { terjed ki) }\end{array}$ & Kötelező & Választható \\
\hline Scope 2 & - & Kötelező & Választható \\
\hline Scope 3 & - & $\begin{array}{l}\text { Választható (a jelentett alkategóriák is } \\
\text { szelektíven választhatók) }\end{array}$ & Választható \\
\hline
\end{tabular}

A széndioxid-elszámolás és a jelentéstétel iránti növekvő érdeklődés felerősítette a terület szabványosítása irányába tett törekvéseket is. Az ÜHG Protokollon, illetve a CDP és a GRI jelentéstételi keretein túl további nemzetközi szabványokat dolgoztak ki. Ezek közül a legfontosabbak közé tartozik a brit PAS 2050 a széndioxid-címkézésre, az ISO 14067 a termékek széndioxidkibocsátására és az ISO 14064 az üvegházhatást okozó gázok jelentéstételére vonatkozóan. Mint mindig, a szabványosítás felveti az összehasonlíthatóság és a vállalatok egyedi jellemzőinek bemutatása közötti átváltás problémáját.

A vállalati szintű széndioxid-elszámolás térnyerése több okból is megvalósulhat:

- szabályozás által vezérelt: a terület szigorúbb szabályozása késztetheti erre a vállalatokat. Például az autóiparban a gépjármüvekre vonatkozó $\mathrm{CO}_{2}-$ kibocsátási előírások szükségessé teszik a széndioxid-elszámolást. Az üvegházhatású gázok európai uniós közösségi kereskedelmi rendszerében a vállalatok egy része - Magyarországon mintegy 160-170 vállalat - köteles éves jelentést készíteni az ÜHG-kibocsátásairól. A kötelező adatgyüjtés miatt e vállalatok könnyüszerrel teljesítik az önkéntes jelentéstételi keretrendszerek tartalmi elvárásait is.

- hatékonyságvezérelt: ha a csökkenő energiafelhasz- vállalat a stratégiai menedzsment szintjén foglalkozzon a széndioxid-elszámolással.

\section{A vállalati széndioxid-elszámolás magyarországi gyakorlata}

Az empirikus felmérés célja, hogy pillanatképet kapjunk a magyarországi vállalatok széndioxid-elszámolási gyakorlatáról, különös tekintettel arra, hogy a vállalatokon átívelő hatásokat mennyiben számszerüsítik, illetve veszik figyelembe a döntéseik során. Szintén a vizsgálat tárgyát képezte, milyen stratégiákat követtek az érintett vállalatok az egyes szervezeteken átívelő széndioxid-kibocsátás kézbentartása érdekében.

\section{A vizsgálat módszere}

Az elsősorban kvalitatív, feltáró jellegü vizsgálat során azt szerettük volna jobban megérteni, milyen területeken számszerüsítik a saját, illetve az ellátási láncuk kibocsátásait a legnagyobb magyarországi kibocsátók. Az egyes területeket a korábban bemutatott ÜHG Protokoll három kategóriája szerint vizsgáltuk. A vizsgálatunkba a Budapesti Értéktőzsdén jegyzett Prémium és Standard kategóriás vállalatokat (összesen 32-t), illetve a HVG 2018-as Top 500-as listájából a tíz legnagyobb árbevételü vállalatot vontuk be. Ez az átfedéseket is figyelembe véve összesen 38 vállalatot jelent. A széndioxid-kibocsátás elszámolását a vállalati környezeti, fenntarthatósági vagy egyéb releváns jelentések legfrissebb verziói alapján vizsgáltuk 
meg, ahol volt ilyen. Ez alapján összesen 16 vállalat elszámolási gyakorlatáról találtunk érdemi információt. Ezek iparág szerinti eloszlása meglehetősen heterogén volt (a legjellemzőbb tevékenységet alapul véve öt energetikai, két-két elektronikai és autógyártó, illetve egy-egy telekommunikációs, pénzügyi, gyógyszeripari, élelmiszeripari, élelmiszer kiskereskedelmi, szállítmányozási vállalat került a mintába, míg egy további vállalat tevékenysége nem volt egyértelmüen besorolható).

\section{Eredmények és értékelésük}

A 16 részletesen megvizsgált vállalat közül 13 közölt számszerü adatokat a széndioxid-kibocsátásáról, ezek minden esetben besorolhatók voltak az ÜHG Protokoll által javasolt kategóriákba is. Három vállalat esetében csak szöveges információt találtunk a széndioxid-kibocsátás csökkentése érdekében tett erőfeszítésekröl. Az ÜHG Protokoll kategóriái szerinti megoszlásokat (kibocsátott mennyiségek alapján százalékosan) a 6. táblázat tartalmazza.

\section{6. táblázat A mintában szereplő vállalatok által elszámolt széndioxid-kibocsátás megoszlása az ÜHG Protokoll kategóriái szerint, \%-ban}

\begin{tabular}{|l|l|l|l|}
\hline \multicolumn{1}{|c|}{$\begin{array}{c}\text { Vállalat } \\
\text { sorszáma }\end{array}$} & \multicolumn{1}{|c|}{$\begin{array}{c}\text { Scope 1 } \\
(\%)\end{array}$} & \multicolumn{1}{|c|}{$\begin{array}{c}\text { Scope 2 } \\
(\%)\end{array}$} & $\begin{array}{c}\text { Scope 3 } \\
(\%)\end{array}$ \\
\hline 1. & $100 \%$ & & \\
\hline 2. & $95 \%$ & $5 \%$ & \\
\hline 3. & $90 \%$ & $10 \%$ & \\
\hline 4. & $100 \%$ & & \\
\hline 5. & $56 \%$ & $44 \%$ & \\
\hline 6. & $10 \%$ & $3 \%$ & $87 \%$ \\
\hline 7. & $22 \%$ & $13 \%$ & $65 \%$ \\
\hline 8. & $44 \%$ & $56 \%$ & \\
\hline 9. & $33 \%$ & $67 \%$ & \\
\hline 10. & $48 \%$ & $52 \%$ & \\
\hline 11. & $12 \%$ & $34 \%$ & $54 \%$ \\
\hline 12. & $49 \%$ & $51 \%$ & \\
\hline 13. & $74 \%$ & $26 \%$ & \\
\hline
\end{tabular}

A táblázat alapján látszik, hogy a közvetlen (Scope 1) kibocsátásokat mind a 13 vállalat nyomon követi, ez ahol külön részletezik - az energiatermeléshez, a közvetlen széndioxid-kibocsátással járó (például gázzal történő) fütéshez, illetve a vállalat saját gépjármüflottájának közvetlen kibocsátásaihoz tartozik. A közvetett kibocsátáson belül a vásárolt energiához kapcsolódó (Scope 2) széndioxid-kibocsátást a vállalatok legnagyobb része, 11 vállalat számszerüsítette, míg csupán két olyan vállalat volt, amely csak a Scope 1 kibocsátásait mutatta be.

A szakirodalmi áttekintésben bemutatottakkal összhangban elmondható, hogy míg a Scope 1 (közvetlen) és Scope 2 (vásárolt energiával összefüggö) kibocsátásokat a legtöbb vizsgált vállalat nyomon követi, az egyéb közvetett, az ellátási lánc egyéb részeire vonatkozó, Scope 3 kibocsátásokat ugyanakkor csak összesen három vállalat számszerüsítette. Kiemelendő ugyanakkor, hogy a kimutatott Scope 3 kategóriába tartozó kibocsátások minden esetben a teljes számszerüsített széndioxid-kibocsátás több mint felét adták (az egyik esetben majdnem 90\%-át). Ugyan a kutatás kvalitatív természete miatt ezeket az értékeket óvatosan kell kezelni, az látszik, hogy a Scope 3 kibocsátások igen jelentősek lehetnek. Sőt, a három konkrét vállalat esetében a Scope 3 kibocsátások a teljes kibocsátás alsó becslése, hiszen csak néhány kategóriát követtek nyomon. A megemlített területek a következők voltak:

- a nyersanyag-kitermeléshez,

- a termék használatához,

- a külső partnerrel végeztetett logisztikai és üzleti utaztatási tevékenységhez, illetve

- a további közvetlen beszállítókhoz és vevőkhöz kapcsolódó, közvetlen és vásárolt energiához kötődő széndioxid-kibocsátások.

A vizsgált vállalatok többsége célkitüzéseket, stratégiát fogalmazott meg a közvetlen, a vásárolt energiához tartozó és az ellátási lánc egyéb területeihez kapcsolódó széndioxid-kibocsátásának csökkentésére vonatkozóan (az utóbbira olyan esetben is sok példa volt, amikor a vállalat nem számszerüsítette a Scope 3 kibocsátásait). Ezen túlmenően néhány vállalat kitért a széndioxid-kibocsátás pénzügyi vonatkozásaira is (vagy legalább a kibocsátás csökkentésében rejlő megtakarítási lehetőségekre).

A Scope 1 (és Scope 2) kibocsátásokkal kapcsolatban a leggyakoribb irányok a következők voltak:

- energiahatékonyság javítása a saját folyamatokat, ingatlanokat és gépjármüveket illetöen,

- anyaghatékonyság javítása (például müanyag alkatrészek újrahasznosítása révén),

- tüzelőanyag megválasztása (különösen a megújuló energiahordozók preferálása),

- munkatársak klíma- és energiatudatosságának növelése képzéssel.

Az ellátásilánc-szemlélet szempontjából fontos egyéb közvetett (Scope 3) kibocsátáscsökkentésre vonatkozóan a vizsgált vállalatok céljai, illetve intézkedései összefoglalóan így néztek ki:

- elvárások megfogalmazása a beszállítók felé,

- vevők, illetve a lakosság energiatudatosságának javítása,

- alacsonyabb széndioxid-kibocsátású termékek (például elektromos autók) népszerüsítése vagy az ezek térnyeréséhez szükséges infrastruktúra (például elektromos vagy földgáz töltőállomások) kialakításában való részvétel,

- intermodális szállítás felé való elmozdulás, üzleti utak kiváltása a telekommunikáció révén.

A vizsgált vállalati gyakorlatok áttekintése alapján az látszik, hogy a széndioxid-kibocsátás számszerüsítése egyelőre leginkább a közvetlen (illetve a vásárolt villamos energiához kötődő) kibocsátásokra terjed ki, az ellátási lánc további részeit jellemző egyéb közvetett (Scope 3) 
kibocsátásokat csak néhány vállalat vizsgálja, még akkor is, ha ezek sokszor jóval jelentősebbek a Scope 1 és 2 kibocsátásoknál. Természetesen a kiterjesztett (közvetett elemeket is tartalmazó) elszámolás átfedéseket tartalmaz (az egyik vállalathoz kötődő Scope 2 vagy 3 kibocsátás egy másik vállalat Scope 1 kibocsátása lehet), a minél szélesebb körü elszámolási fókusz segíthet az ellátási láncok mentén a lényeges kibocsátási pontok észlelésében és a csökkentési prioritások meghatározásában. (A teljesség kedvéért meg kell említeni, hogy ugyan a vizsgálat során az ÜHG Protokoll kategóriáit használtuk, a vizsgált vállalati elszámolások a széndioxid-kibocsátás nyomon követésére koncentráltak, egyéb üvegházgáz-kibocsátások vizsgálatára, illetve tágabb értelemben a klímahatás-elszámolásra nem terjedtek ki.)

\section{Összegzés és kitekintés}

A klímaváltozással kapcsolatos növekvő társadalmi tudatosság és a területet szabályozni kívánó nemzetközi egyezmények eredményeként a vállalati széndioxid-elszámolás is egyre fontosabbá vált az elmúlt néhány évtizedben. A terület fejlődését nagymértékben ösztönözte, hogy a globálissá váló ellátási láncok, illetve a hálózati gazdaság korában olyan elszámolási eszközökre van szükség, amelyek túlmutatnak az egyes vállalatok közvetlen kibocsátásainak elkülönülten történő vizsgálatán. A cikk egyik fontos elméleti hozzájárulása, hogy a széndioxidkibocsátás elszámolásának fejlődését négy szakaszra osztottuk, melyek különböző fókuszokkal jellemezhetők. A koncepció gyökerei az 1990-es évekre, a környezeti számvitel kialakulásának idejére nyúlnak vissza, de ezen belül a nemzetközi klímapolitikában bekövetkező előre lépések eredményeként a széndioxid-elszámolás hamar kiemelt területté vált. A 2000-es évek közepétöl egyre hangsúlyosabb lett az ellátási lánc, illetve termékéletciklus szintü széndioxid-elszámolás módszertanának fejlődése, amelynek a vállalati gyakorlatba történő átültetése szempontjából kiemelt fontosságú eszköze az ÜHG Protokoll. A szén- és egyéb üvegházhatást okozó gázok kibocsátásának számszerűsítésén túl a legújabb tendencia az éghajlatváltozáshoz kötődő vállalati alkalmazkodási költségek elszámolása. A kifejlesztett kategorizálás segítséget nyújthat a vállalati gyakorlat vizsgálatához, fejlesztéséhez is, így az akadémiai olvasóközönségen túl a vállalati szakemberek számára is hasznos lehet. Ez különösen a jelenleg még folyamatosan fejlődő klímahatás-elszámolás esetében fontos, ahol a pontos tartalom lehatárolásához még további kutatások szükségesek.

A vállalati széndioxid-elszámolás harmadik szakaszától kezdve (amióta egyre nagyobb hangsúly van a vállalatokon átívelő kibocsátások számszerüsítésén) az elszámolás módszertana sokat finomodott, de azért még akad tennivaló a területen. Ilyen például az ellátási láncok mentén történő elszámolások során a rendszerhatárok pontos lehatárolása és a Scope 3 kibocsátások számszerüsítésének további finomítása.

A széndioxid-elszámolások gyakorlati vonatkozásai közül már a kezdetektől fontos kérdés az önkéntes és a kötelező jelentéstétel kapcsolata. Az önkéntes jelentésté- tel területén ugyan vannak jó gyakorlatok (mint például a CDP), de nem valószínü, hogy a közeljövőben ezekhez a kezdeményezésekhez a vállalatok többsége csatlakozna. Különösen a gyengébben teljesítők távolmaradása várható, még ha ez nemcsak a gazdaság versenyképessége, hanem a társadalom tágabb értelemben vett jólléte szempontjából is kedvezőtlen fejlemény (Kerekes, 2011). A kötelező jelentések bizonyos mértékig kitölthetik ezt a hiányosságot, de néhány szórványos példán kívül még nem látható, hogy mindez hogyan valósulhat meg.

További fontos kihívás a széles körü széndioxid-elszámolások eröforrás-igénye. A nagyobb vállalatok ugyan nagyobb eséllyel rendelkeznek erre vonatkozóan megfelelő pénzügyi és humán erőforrásokkal, a kisebbek azonban nagy valószínűséggel hiányt szenvednek a területen. A piacon ugyan számos egyszerübb, ingyenesen hozzáférhető vállalati szénlábnyom-kalkulátor érhetö el, de ezek pillanatnyilag nem elég fejlettek a vállalati széndioxidkibocsátások érvényes és megbízható nyomon követésére (Szigeti \& Harangozó, 2016).

A széndioxid-elszámolás magyarországi gyakorlata sok tekintetben összhangban van a szakirodalmi áttekintésben feltárt tendenciákkal. A vállalati elemzés alapján elmondható, hogy a legnagyobb vállalatok már komoly figyelmet fordítanak a széndioxid-elszámolásra, a közvetlen (Scope 1) és a vásárolt energiához kapcsolódó (Scope 2) kibocsátásaikat nagyrészt számszerüsítik, míg az egyéb közvetett, az ellátási lánc további szereplőinél megjelenő (Scope 3) kibocsátások elszámolása még gyerekcipőben jár. Érdekes ugyanakkor, hogy annál a néhány vállalatnál, ahol a Scope 3 kibocsátások számszerüsítésével is megpróbálkoztak (akár csak néhány összetevőjére vonatkozóan), az ide tartozó kibocsátások minden esetben meghaladták a közvetlen és a vásárolt energiához kapcsolódó közvetett kibocsátások értékét. A magyarországi áttekintés alapján elmondható, hogy a széndioxidelszámolás gyakorlata - néhány élen járó vállalatot kivéve - nem használja ki a meglevő módszertani keretet. További kutatás tárgyát képezheti, hogy nagyobb elemszámú nemzetközi adatbázisok (például a Carbon Disclosure Project adatbázisa) alapján vizsgáljuk meg a legjobb vállalati gyakorlatot, különös tekintettel a Scope 3 kibocsátások elszámolására vonatkozóan.

\section{Felhasznált irodalom:}

Banuri, T. (2009). Climate change and sustainable development. Natural Resources Forum, 33(4), 257-258.

Bennett, M. \& James, P. (eds.) (1998). The Green bottom line: environmental accounting for management: current practice and future trends. Austin, TX: Greenleaf Publishing.

Bilec, M., Ries, R., Matthews, H.S., \& Sharrard, A.L. (2006). Example of a hybrid life-cycle assessment of construction processes. Journal of Infrastructure System, 12(4), 207-215.

Blanco, C., Caro, F., \& Corbett, C. J. (2016). The state of supply chain carbon footprinting: analysis of CDP disclosures by US firms. Journal of Cleaner Production, 135, 1189-1197. 
Boden, T.A., Marland, G., \& Andres, R.J. (2017). Global, Regional, and National Fossil-Fuel $\mathrm{CO}_{2}$-Emissions. Oak Ridge, Tenn.: Carbon Dioxide Information Analysis Center, Oak Ridge National Laboratory, U.S. Department of Energy.

Burritt, R. L. \& Tingey-Holyoak, J. (2012). Forging cleaner production: the importance of academic-practitioner links for successful sustainability embedded carbon accounting. Journal of Cleaner Production, 36, 39-47.

Cagiao, J., Gómez, B., Doménech, J.L., Mainar, S.G., \& Lanza, H.G. (2011). Calculation of the corporate carbon footprint of the cement industry by the application of MC3 methodology. Ecological Indicators, 11(6), 1526-1540.

Carbon Disclosure Project, CDP (2016). www.cdp.net, last accessed at $25^{\text {th }}$ August 2016.

Carbon Trust (2008). Product Carbon Footprinting. The New Business Opportunity. Experiences from Leading Companies. London, UK: Carbon Trust.

Carbon Trust (2016). www.carbontrust.com, Letöltve: 2018.10.17.

CCAR (2008). California Climate Action Registry General Reporting Protocol. Los Angeles, CA: California Climate Action Registry.

Crawford, R. H. (2008). Validation of a hybrid life-cycle inventory analysis method. Journal of Environmental Management, 88(3), 496-506.

Csutora, M. \& Vetőné Mózner, Z. (2014). Proposing a beneficiary-based shared responsibility approach for calculating national carbon accounts during the postKyoto era. Climate Policy, 14(5), 599-616.

DEFRA (2013). Environmental Reporting Guidelines: Including mandatory greenhouse gas emissions reporting guidance. London, UK: UK Department for Environment, Food and Rural Affairs.

Deutsch, N. \& Pintér, É. (2018). The link between Corporate Social Responsibility and Financial Performance in the Hungarian Banking Sector in the Years following the Global Crisis. Financial and Economic Review, 17(2), 124-145.

Downie, J. \& Stubbs, W. (2012). Corporate carbon strategies and greenhouse gas emission assessments: The implications of Scope 3 emission factor selection. Business Strategy \& The Environment, 21(6), 412-422.

Downie, J. \& Stubbs, W. (2013). Evaluation of Australian companies' Scope 3 greenhouse gas emissions assessments. Journal of Cleaner Production, 56, 156-163.

EEA (European Environment Agency) (2010). SOER Synthesis, 2010. The European Environment. State and Outlook 2010: Synthesis. Copenhagen, Denmark: Office for Official Publications of the European Union.

Eurobarometer (2007): Attitudes of European citizens towards the environment. Special Eurobarometer 295, Summary. Brussels, Belgium: European Commission.

Eurobarometer (2011): Attitudes of European citizens towards the environment. Special Eurobarometer 365. Brussels, Belgium: European Commission.

Farsan, I., Chang, A., Kerkhof, A., Cserna, B., Yan, C., \& Villasana, R. (2018). Value change in the value chain:
Best practices in Scope 3 greenhouse gas management. Science Based Targets.

Galli, A., Wiedmann, T., Ercin, E., Knoblauch, D., Ewing, B., \& Giljum, S., (2012). Integrating ecological, carbon and water footprint into a "Footprint Family" of indicators: definition and role in tracking human pressure on the planet. Ecological Indicators, 16, 100-112.

Gelei A. \& Nagy J (2017). Ellátási hálózatok alapvető struktúrái. In Varga Bálint (szerk.), Logisztikai Évkönyv (pp. 93-104). Budapest, Magyarország: Magyar Logisztikai Egyesület.

Görbe, Sz. \& Gelei, A. (2014). „Mennyit ér” a fenntarthatóság? - Esettanulmány az externális hatások mérésére azok internalizálására Vezetéstudomány, 45(7-8), $15-28$.

Harangozo, G. \& Szigeti, C. (2017). Corporate carbon footprint analysis in practice - With a special focus on validity and reliability issues. Journal of Cleaner Production, 167, 1177-1183.

Harangozo, G., Szechy, A., \& Zilahy, G. (2015). Corporate Sustainability Footprints - A Review of Current Practices. In: Schaltegger, Zvezdov, Alvarez, Csutora, \& Günther (eds.), Corporate Carbon and Climate Accounting (pp. 45-76). Cham: Springer International Publishing.

Huang, Y.A., Weber, C.L., \& Matthews, H.S. (2009). Categorization of scope 3 emissions for streamlined enterprise carbon footprinting. Environmental Science \& Technology, 43(22), 8509-8515.

IEA (International Energy Agency) (2011). $\mathrm{CO}_{2}$ emissions from fuel combustions highlights. Paris, France: IEA/ OECD.

IPCC (Intergovernmental Panel on Climate Change) (2007). Climate Change 2007. The physical science basis. Contribution of working group I to the fourth assessment report of the Intergovernmental Panel on Climate Change. Cambridge, UK: Cambridge University Press.

ISO (International Organization for Standardization) (2006a). Environmental management - Life cycle assessment-Principles and framework (ISO 14040:2006). Berlin, Germany: Beuth.

ISO (International Organization for Standardization) (2006b). Environmental management - Life cycle assessment - Requirements and guidelines (ISO 14044:2006). Berlin, Germany: Beuth.

Jasch, C. (2003). The use of Environmental Management Accounting (EMA) for identifying environmental costs. Journal of Cleaner Production, 11(6), 667-676.

Jungbluth, N., Büsser, S., Frischknecht, R., Flury, K., \& Stucki, M. (2012). Feasibility of environmental product information based on life cycle thinking and recommendations for Switzerland. Journal of Cleaner Production, 28, 187-197.

Kerekes S. (2011). Happiness, environmental protection and market economy. Society and Economy, 33(1), 5-13.

Kovács, L., Pónusz, M., \& Kozma, T. (2018). A zöld beszerzés stratégiai jelentősége. Logisztikai Trendek és Legjobb Gyakorlatok, 4(1), p. 28-32. 
Lee, K.-H. \& Vachon, S. (2016). Supply Chain Sustainability Risk. In Lee, K.-H. \& Vachon, S., Business Value and Sustainability (pp. 245-280). London, UK: Palgrave McMillan.

Lenzen, M. (2002). A guide for compiling inventories in hybrid life-cycle assessments: some Australian results. Journal of Cleaner Production, 10(6), 545-572.

Leontief, W.W. (1936). Quantitative input and output relations in the economic systems of the United States. The Review of Economic Statistics, 105-125.

Matthews, H., Hendrickson, C., \& Weber, C. (2008). The importance of carbon footprint estimation boundaries. Environmental Science \& Technology, 42(16), 58395842.

Marjainé Szerényi, Z. \& Kocsis, T. (2018). Gazdag szegények: Időráfordítási hajlandóság a környezeti javak értékelésében. Közgazdasági Szemle, 65(11), 1154-1171.

Meisterling, K., Samaras, C., \& Schweizer, V. (2009). Decisions to reduce greenhouse gases from agriculture and product transport: LCA case study of organic and conventional wheat. Journal of Cleaner Production, 17, 222-230.

OPEN:EU (2010). OPEN:EU Scenario Scoping Report. One Planet Economy Network: Europe project. http:// www.oneplaneteconomynetwork.org/resources/programmedocuments/Scenario Scoping Report.pdf. Letöltve 2018.10.11.

Ozawa-Meida, L., Brockway, P., Letten, K., Davies, J., \& Fleming, P. (2013). Measuring carbon performance in a UK University through a consumption-based carbon footprint: De Montfort University case study. Journal of Cleaner Production, 56, 185-198.

Patchell, J. (2018). Can the implications of the GHG Protocol's Scope 3 standard be realized? Journal of Cleaner Production, 185, 941-958.

Pellegrino, C. \& Lodhia, S. (2012). Climate change accounting and the Australian mining industry: exploring the links between corporate disclosure and the generation of legitimacy. Journal of Cleaner Production, 36, 68-82.

Pintér, T. (2015). Integrált városfejlesztés az Európai Unió keleti és nyugati tagállamaiban - Románia és Németország esete. Journal of Central European Green Innovation, 3, 123-136.

Pónusz, M. \& Kozma, T. (2017). Zöld ellátási láncok és innovatív megoldások. Logisztikai Trendek és Legjobb Gyakorlatok, 3(2), 61-66.

Schaltegger, S. \& Burritt, R. (2000). Contemporary environmental accounting: issues, concepts and practice. Austin, TX: Greenleaf Publishing.

Schaltegger, S. \& Csutora, M. (2012). Carbon accounting for sustainability and Management. Status quo and challenges. Journal of Cleaner Production, 36, $1-16$.

Scipioni, A., Manzardo, A., Mazzi, A., \& Mastrobuono, M. (2012). Monitoring the carbon footprint of products: a methodological proposal. Journal of Cleaner Production, 36, 94-101.

Stechemesser, K. \& Guenther, E. (2012). Carbon account- ing: a systematic literature review. Journal of Cleaner Production, 36, 17-38.

Stechemesser, K., Bergmann, A., \& Günther, E. (2015). Organizational Climate Accounting - Financial Consequences of Climate Change Impacts and Climate Change Adaptation. In: Schaltegger, Zvezdov, Alvarez, Csutora, \& Günther (eds.), Corporate Carbon and Climate Accounting (pp. 217-242). Cham: Springer International Publishing.

Stein, M. \& Khare, A. (2009). Calculating the carbon footprint of a chemical plant: A case study of Akzonobel. Journal of Environmental Assessment Policy \& Management, 11(3), 291-310.

Stern, N. (2007). The economics of climate change: The Stern review. Cambridge, UK: Cambridge University Press.

Suh, S., Lenzen, M., Treloar, G. J., Hondo, H., Horvath, A., \& Huppes, G. (2004). System boundary selection in life cycle inventories using hybrid approaches. Environmental Science and Technology, 38, 657-664.

Széchy, A. \& Zilahy, G. (2018). Vállalati környezeti menedzsment Magyarországon - az elmúlt húsz év tapasztalatai. In: Környezet, gazdaság, társadalom. Tanulmányok Kerekes Sándor 70. születésnapja tiszteletére (pp. 168-179). Kaposvár, Magyarország: Kaposvári Egyetem Gazdaságtudományi Kar.

Szendrey, O. \& Karcagi-Kováts, A. (2016). Klímatárgyalások vizsgálata mátrixjátékokkal. Köztes Európa: Társadalomtudományi Folyóirat, 8(19-20), 292-301.

Szendrey, O. \& Karcagi-Kováts, A. (2018). Környezeti egyezmények betartathatóságának vizsgálata játékelméleti módszerekkel. Taylor: Gazdálkodás-és Szervezéstudományi Folyóirat, 10(3), 67-78.

Szigeti C. (2016). Az ökológiai lábnyom határai. Budapest, Magyarország: Typotex.

Tóth, G. \& Szigeti, C. (2016). The historical ecological footprint: From over-population to over-consumption. Ecological Indicators, 60, 283-291.

Tóth G. et al. (2002-2017). Ablakon bedobott pénz - Magyarországi szervezetek esettanulmányai környezeti és gazdasági megtakaritást egyszerre hozó intézkedésekröl (I. - XII. kötet). Budapest, Magyarország: KÖVET.

Tóth, G., Szigeti, C., Harangozó, G., \& Szabó, D. (2018). Ecological footprint at the micro-scale - how it can save costs: The case of ENPRO. Resources, 7(3), 45-69.

Townsend, J. \& Barrett, J. (2013). Exploring the applications of carbon footprinting towards sustainability at a UK university: reporting and decision making. Journal of Cleaner Production.

Toyota Motor Corporation (2018). Sustainability Data Book 2018. https://www.toyota-global.com/sustainability/report/archive/sr18/pdf/sdb18_full_en.pdf, letöltve 2019.01.14.

UNFCCC (2016). Paris Agreement. http://unfccc.int/ files/meetings/paris_nov_2015/application/pdf/paris_ agreement_english_.pdf, letöltve 2018.08.18.

Vázquez-Rowe, I., Villanueva-Rey, P., Mallo, J., De la Cerda, J., Moreira, T., \& Feijoo, G. (2013). Carbon footprint of a multi-ingredient seafood product from a 
business-to-business perspective. Journal of Cleaner Production, 44, 200-210.

Vetőné Mózner, Zs. (2012). Fogyasztási szokások és trendek vizsgálata Európában és az USA-ban. In Fenntartható fogyasztás? Trendek és lehetőségek Magyarországon. OTKA 68647 kutatás eredményei (pp. 24-40). Budapest, Magyarország: AULA.

Vörösmarty, G. \& Dobos, I. (2019). Supplier Evaluation with Environmental Aspects and Common DEA Weights. Periodica Polytechnica, 27(1), 17-25.

von Weizsäcker, E.U., Hargroves, K., Smith M.H., \& Desha, C. (2009). Factor five. Transforming the global economy through $80 \%$ Improvements in resource productivity. London, UK: Taylor \& Francis.

von Weizsäcker, E.U., Lovins, A.B., \& Lovins, L.H. (1997). Factor four: doubling wealth - halving resource use. London, UK: Earthscan.

Wackernagel, M., Onisto, L., Bello, P., Linares, A.C., Falfán, L., García, J.M., Suárez, G.A.I., \& Suárez, G.M.G. (1999). National natural capital accounting with the ecological footprint concept. Ecological Economics, 29(3), 375-390.

WBCSD/WRI (2004). The Greenhouse Gas Protocol - A Corporate Accounting and Reporting Standard. Geneva, Switzerland: World Business Council for Sustainable Development and World Resources Institute.

WBCSD/WRI (2011). The Greenhouse Gas ProtocolCorporate Value Chain (Scope 3) Accounting and Reporting Standard. Supplement to the GHG Protocol Corporate Accounting and Reporting Standard.
Geneva, Switzerland: World Business Council for Sustainable Development and World Resources Institute.

Weber, C., Peters, G.P., Guan, D., \& Hubacek, K. (2008). The contribution of Chinese exports to climate change. Energy Policy, 36, 3572-3577.

Wiedmann, T.O., Lenzen, M., \& Barrett, J.R. (2009). Companies on the scale comparing and benchmarking the sustainability performance of businesses. Journal of Industrial Ecology, 13(3), 361-383.

Zsóka, Á. \& Vajkai, É. (2018). Corporate sustainability reporting: scrutinising the requirements of comparability, transparency and reflection of sustainability performance. Society and Economy, 40(1), $19-41$

525/2013/EU rendelet az üvegházhatást okozó gázok kibocsátásának nyomon követésére és bejelentésére, valamint az éghajlatváltozással kapcsolatos egyéb információk nemzeti és uniós szintü bejelentésére szolgáló rendszerről, valamint a 280/2004/EK határozat hatályon kívül helyezéséröl.

2012. évi CCXVII. törvény az üvegházhatású gázok közösségi kereskedelmi rendszerében és az erőfeszítés-megosztási határozat végrehajtásában történő részvételről.

410/2012. (XII. 28.) Korm. rendelet az üvegházhatású gázok közösségi kereskedelmi rendszerében és az erőfeszítés-megosztási határozat végrehajtásában való részvételről szóló 2012. évi CCXVII. törvény végrehajtásának egyes szabályairól. 